\title{
ASSESSMENT OF THE PHYSICAL AND PHYSIOLOGICAL QUALITY OF Piptadenia gonoacantha SEEDS (MART.) J. F. MACBR. USING IMAGE ANALYSIS
}

Daniel Teixeira Pinheiro $2^{*} \mathcal{C}^{+}$, Nayara Pereira Capobiango ${ }^{2} \mathcal{C}^{\circ}$, André Dantas de Medeiros ${ }^{2} \mathcal{C}^{\circ}$, Karine Fernandes Caiafa $^{3}$, Denise Cunha Fernandes dos Santos Dias $^{2} \cdot$ and Antônio Lelis Pinheiro ${ }^{3}$

\footnotetext{
${ }^{1}$ Received on 04.04.2020 accepted for publication on 12.06.2020.

${ }^{2}$ Universidade Federal de Viçosa, Departamento de Agronomia, Viçosa, MG-Brasil. E-mail: <pinheiroagroufv@gmail.com>, <nayara. capobiango@hotmail.com>,<andre.d.medeiros@ufv.br>and<dcdias@ufv.br>.

${ }^{3}$ Universidade Federal de Viçosa, Departamento de Engenharia Florestal, Viçosa, MG-Brasil E-mail: <karine.fernandes.caiafa@gmail. com> and <pinheiroufv@gmail.com>.

*Corresponding author.
}

\begin{abstract}
The assessment of the quality of native forest species seeds is extremely important and, in this sense, it is necessary to integrate new technologies that can complement the quality analysis traditionally used. This study aimed to evaluate the physical and physiological quality of Piptadenia gonoacantha seeds using image analysis techniques and to relate aspects of tissue integrity with physiological attributes. Seeds from 10 lots were collected and submitted to automatic and visual analyses of radiographic images, with the determination of parameters related to tissue density and seed filling. After the X-ray test, the seeds were subjected to physiological analyses of germination and vigor. It was observed that the lots that presented higher values of tissue density, filling, and solidity, presented higher germination and vigor. It was also evident that the damage present in the seeds was causally related their physiological condition. Therefore, the results showed that the use of the X-ray technique in seeds combined with the automated analysis of the radiographs is efficient in the evaluation of the internal morphology of $P$. gonoacantha seeds. The physical integrity of the seed tissues is directly related to the physiological quality and allows the classification of different lots as to vigor. Visual analysis of digital radiographs is adequate to identify malformation in $P$. gonoacantha seeds.
\end{abstract}

Keywords: Native species; X-ray; Vigor.

\section{AVALIAÇÃO DA QUALIDADE FÍSICA E FISIOLÓGICA DE SEMENTES DE Piptadenia gonoacantha (MART.) J. F. MACBR. UTILIZANDO ANÁLISE DE IMAGENS}

RESUMO - A avaliação da qualidade das sementes de espécies florestais nativas é de extrema importância $e$, neste sentido, há a necessidade de integrar novas tecnologias que possam complementar as análises de qualidade tradicionalmente utilizadas. O objetivo desse estudo foi avaliar a qualidade fisica e fisiológica de sementes de Piptadenia gonoacantha utilizando técnicas de análise de imagem e relacionar aspectos de integridade tecidual com atributos fisiológicos. Sementes de 10 lotes foram coletadas e submetidas a análises automáticas e visuais de imagens radiográficas, com a determinação de parâmetros relacionados à densidade tecidual e preenchimento das sementes. Após o teste de raios- $X$, as sementes foram submetidas a análises fisiológicas de germinação e vigor. Foi observado que os lotes que apresentaram maiores valores de densidade tecidual, preenchimento e solidez, apresentaram maior germinação e vigor. Ficou evidente também que os danos presentes nas sementes tiveram relação direta com o seu desempenho fisiológico. Portanto, os resultados mostraram que a técnica de raios X nas sementes, combinada com a análise automatizada das radiografias, são eficientes na avaliação da morfologia interna de sementes de P. gonoacantha. A integridade fisica dos tecidos das sementes está diretamente relacionada à qualidade fisiológica e permite a classificação de diferentes 
lotes quanto ao vigor. A análise visual de radiografias digitais é adequada para identificar a má formação em sementes de P. gonoacantha.

Palavras-Chave: Espécie nativa; raios-X; Vigor.

\section{INTRODUCTION}

The demand for seeds of native forest species has increased considerably in Brazil through the law $\mathrm{n}^{\circ}$. 12,651 , which aims to protect native vegetation in the country, including areas of permanent preservation and legal reserve (Brasil, 2012). Therefore, the evaluation of the quality of seeds of native forest species is extremely important for the production and establishment of quality seedlings.

Piptadenia gonoacantha (Mart.) JF Macbr., popularly known as "pau-jacaré", is a tree species native to the Atlantic Forest belonging to the Fabaceae family and has its natural occurrence in the South and Southeast regions of Brazil (Moura et al., 2017). It has economic, social and environmental importance, because, in addition to being useful in the production of furniture, energy, cellulose, and paper. This specie has also ecological relevance in restoration programs for degraded areas, due to its contribution in carbon storage (Torres et al., 2017).

The evaluation of seed quality is usually performed through a germination test and complemented by vigor tests. However, these analyses are destructive and generally time-consuming and may take several days to obtain the results. In this sense, there is a need to integrate new technologies that allow obtaining results in a short period of time, combined with a nondestructive method, allowing the use of the seeds for other purposes. Therefore, image analysis of seeds with techniques such as X-rays have shown to be promising for assessing physical characteristics related to physiological potential, in a non-destructive, fast and efficient way (Al-Hammad and Al-Ammari, 2017; Al-Turki and Baskin, 2017; Leão-Araújo et al., 2019). In a different way, the automated seedling analysis is destructive. However, it's also shown promise, since it allows with a single image, the achievement of several attributes, such as length and indexes related to vigor (Sako et al., 2001; Brunes et al., 2016).

Studies with radiographic images of seeds and automated analysis of seedlings have been shown to be efficient in identifying and determining several physical and physiological descriptors in seeds of forest species, such as Terminalia argentea (Gomes et al., 2014), Platypodium elegans (Gomes et al., 2016), Moringa oleifera (Noronha et al., 2018), Leucaena leucocephala (Medeiros et al., 2018; Medeiros et al., 2019), Moquiniastrum polymorphum (Faria et al., 2019) and others. Seed viability is not compromised when subjected to X-ray analysis, due to the low radiation intensity to which the seeds are exposed. Therefore, it makes it possible to carry out additional analysis such as germination, for later correlation between structural integrity and physiological potential (Gagliardi and Marcos-Filho, 2011).

Studies on the quality monitoring of $P$. gonoacantha seeds through image analysis are scarce. This study aimed to evaluate the physical and physiological quality of seeds of Piptadenia gonoacantha using image analysis techniques and to relate aspects of tissue integrity with physiological attributes.

\section{MATERIAL AND METHODS}

\subsection{Site and plant material}

P. gonoacantha seeds were obtained from fruits collected from 10 different mother trees, randomly selected in an experimental area at the Universidade Federal de Viçosa, DEF / UFV, in 2019, in the municipality of Viçosa, state of Minas Gerais, Brazil (2046'01.7"S $\left.42^{\circ} 52^{\prime} 05.6^{\prime \prime} \mathrm{W}\right)$. Therefore, the seeds collected from the different mother trees constituted 10 lots, which formed the 10 treatments.

The seeds were manually extracted from the fruits and placed to dry at room temperature for 120 hours until they reached hygroscopic balance (about 12\% of moisture content).

\subsection{X-ray test: automatic and visual analysis of radiographs}

The seeds were subjected to analysis of their internal tissues using the X-ray technique applied to 100 seeds from each treatment, fixed in groups of 10 seeds in an orderly and equidistant manner on adhesive paper.

Revista Árvore 2020;44:e4426 
This procedure was performed to allow the individual identification of each seed in the subsequent analyses.

The radiographic images were generated by a Faxitron device, model MX-20 (Faxitron X-ray Corp. Wheeling, IL, USA). The equipment was adjusted to a voltage of $23 \mathrm{kV}$ and the seeds were exposed to radiation for 10 seconds, at a focal distance of $41.6 \mathrm{~cm}$. The image contrast was calibrated at 1872 (width) x 1907 (center). The images were saved in Tagged Image File Format (TIFF) and then analyzed.

The automated analysis of the images was made using the free software Image ${ }^{\circledR}$ (https://imagej.nih. gov/ij/download.html), with the aid of the PhenoXray macro (Medeiros et al., 2019b). The sequential analysis performed by the macro consisted of scale calibration (59,6003 pixels / $\mathrm{mm}$ was adopted), opening of the images, segmentation, and extraction of different tissue integrity descriptors of each seed contained in the image.

In more detail, each open image was duplicated and the segmentation was done in the copy of the image. The Threshold mode of Image ${ }^{\circledR}$ was used through Yen's automatic multilevel thresholding method (Yen et al., 1995) for segmentation. Then, the selections in the binary image were redirected to the original image. Finally, the seeds were analyzed using the command "analyze particles", which generated the following descriptors:

Relative density (gray.pixel ${ }^{-1}$ ): defined as the average of the gray values of all pixels in the selected area;

Integrated density (gray.mm.pixel ${ }^{-1}$ ): sum of the pixel values in the image or selection;

Seed filling (\%): was determined by dividing the area with levels of ash above the threshold defined by the total area of each seed.
Solidity: obtained through the equation:

$$
\text { Solidity }=\frac{\text { (Area of the object) }}{\text { (Area of the convex closure) }} \text {. }
$$

In this equation, values equal to 1.0 indicate that the object is solid; and less than 1.0 objects with irregular edges or holes.

For the visual evaluation of radiographic images, the seeds were individually separated into three classes: well-formed (containing dense and essential tissues for germination) (Class 1; Figure 1A); wellformed and damaged (well-formed seed with any type of physical damage (insect and / or mechanic), apparent in the integument or embryo) (Class 2; Figure 1B); and malformed (opaque, with deformed and / or empty embryo) (Class 3; Figure 1C).

\subsection{Physiological analyses}

After obtaining the radiographic images, the seeds were tested for their physiological quality. For this purpose, the germination test was conducted on paper towels rolls for germination $\left(\right.$ Germitest $\left.{ }^{\circledR}\right)$, moistened with an amount of water equivalent to 2.5 times the mass of the dry paper, which were kept in a germinator at $25{ }^{\circ} \mathrm{C}$ for 10 days. Germination (root protrusion) and normal seedlings were counted every day. From these data, the percentages of: root protrusion (root greater than $2 \mathrm{~mm}$ ) and normal seedlings, germination speed index (GSI) and 50\% germination time (t50) were calculated according to the formulas described by Silva et al. (2019). After the last counting was made, seedlings and the non-germinated seeds of each repetition were photographed and the generated images were evaluated in the Image ${ }^{\circledR}$ software. The images were used to measure seedling length, expressed in mm.seedling ${ }^{-1}$. Subsequently, the seedlings were dried in an oven with forced air circulation at $65{ }^{\circ} \mathrm{C}$ until
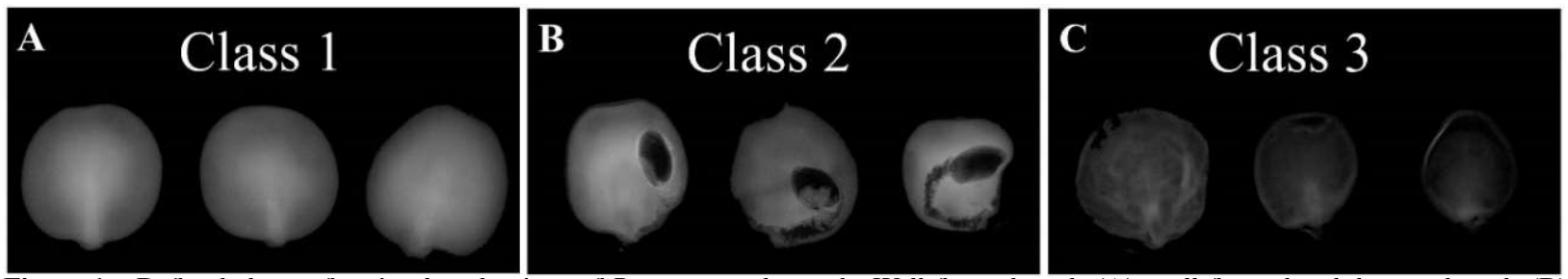

Figure 1 - Defined classes for visual evaluations of P. gonoacantha seeds. Well-formed seeds (A), well-formed and damaged seeds (B) and malformed seeds $(\mathrm{C})$.

Figura 1 - Classes definidas para avaliações visuais de sementes de P. gonoacantha. Sementes bem formadas (A), sementes bem formadas com danos $(B)$ e sementes malformadas $(C)$. 
weight stabilization, with subsequent weighing on a precision scale to determine the dry matter mass, with the results expressed in mg. seedling ${ }^{-1}$.

\subsection{Experimental design and statistical analysis}

The experiment was conducted in a completely randomized design (CRD) with five replications. The data were subjected to analysis of variance since the normal distribution of the error and the homogeneity of the variances were verified by the ShapiroWilk and Bartlett tests. The treatment means were compared using the Scott-Knott test $(p \leq 0.05)$. The mean values of the radiographic image analysis data and the physiological tests of each treatment were used to perform the Principal Component Analysis (PCA), where an " $\mathrm{x}$ p" matrix was obtained, where " $n$ " corresponds to the number of treatments $(n=10)$ and " $p$ " the number of variables analyzed $(p=13)$. The eigenvalues and eigenvectors were calculated from the covariance matrices and plotted on a twodimensional graph (category ordering diagram and correlation circle), generated from the Factoextra package (Kassambara and Mundt, 2016). Pearson's correlation ( $r$ ) was calculated with the data obtained in all evaluations for all treatments. The software $\mathrm{R}$ 3.5.1 (R Development Core Team, 2018) was used in all analyses.

\section{RESULTS}

Through physical analysis (automated and visual) by the X-ray test, it was observed significant differences between the evaluated lots. For tissue density (relative and integrated), lots 1 and 2 presented, in general, higher values and lot 10 values were lower than the others (Table 1).

Seed filling showed a similar trend to tissue density, with lots 1, 2 and 9 being superior and lot 10 being inferior to the others. For solidity, lot 10 was inferior and the other lots had, in general, similar behavior among them (Table 1).

The visual physical analysis indicated that lots 1 , 5, 6 and 9 presented a higher percentage of well-formed seeds (Class 1) compared to the others. Lots 2 and 7 had the highest proportion of well-formed and damaged seeds (Class 2) and lot 10 had the highest percentage of malformed seeds (Class 3) (Table 1).

The physiological analyses showed that lots 1,2 , 5,6 and 9 had a higher percentage of root protrusion, normal seedlings, in addition to higher GSI values (Table 2).

Lot 10 was inferior to the others, presenting only $2 \%$ of root protrusion and null values of normal seedlings, GSI and t50. Lots 1, 2 and 9 in addition to higher values of

Table 1 - Descriptors evaluated by automated and visual analysis of radiographic images of different $P$. gonoacantha seed lots. Means represented by the same letter do not differ by the Scott-Knott test $(p \leq 0.05)$

Tabela 1 -Descritores avaliados por análises automatizadas e visuais de imagens radiográficas de diferentes lotes de sementes de $\boldsymbol{P}$. gonoacantha. Médias representadas pela mesma letra não diferem entre si pelo teste de Scott-Knott (p $\leq 0.05)$.

\begin{tabular}{|c|c|c|c|c|c|c|c|}
\hline \multirow[b]{2}{*}{ Lots } & \multicolumn{3}{|c|}{ Automated analysis } & \multirow[b]{2}{*}{ Solidity } & \multicolumn{3}{|c|}{ Visual analysis } \\
\hline & $\begin{array}{l}\text { Rel. Dens. } \\
\left(\text { gray.pixel }^{-1}\right)\end{array}$ & $\begin{array}{c}\text { Int. Dens. } \\
\text { (gray.pixel.mm }{ }^{-1} \text { ) }\end{array}$ & Filling (\%) & & Class $1(\%)$ & Class $2(\%)$ & Class $3(\%)$ \\
\hline 1 & $82.883 \mathrm{a}$ & $3588.493 \mathrm{a}$ & $97.42 \mathrm{a}$ & $0.969 \mathrm{a}$ & $66 \mathrm{a}$ & $22 b$ & $12 \mathrm{f}$ \\
\hline 2 & $82.848 \mathrm{a}$ & $3919.772 \mathrm{a}$ & $97.10 \mathrm{a}$ & $0.957 \mathrm{~b}$ & $50 \mathrm{~b}$ & $37 \mathrm{a}$ & $13 \mathrm{f}$ \\
\hline 3 & $59.859 \mathrm{~b}$ & $2457.651 \mathrm{~b}$ & $96.45 \mathrm{~b}$ & 0.969 a & $43 \mathrm{~b}$ & $17 \mathrm{~b}$ & $40 \mathrm{c}$ \\
\hline 4 & $64.462 \mathrm{~b}$ & $2941.201 \mathrm{~b}$ & $95.90 \mathrm{~b}$ & $0.964 \mathrm{a}$ & $39 \mathrm{~b}$ & $15 \mathrm{~b}$ & $48 \mathrm{c}$ \\
\hline 5 & $85.940 \mathrm{a}$ & $4400.647 \mathrm{~b}$ & $96.46 \mathrm{~b}$ & $0.966 \mathrm{a}$ & $82 \mathrm{a}$ & $14 \mathrm{~b}$ & $5 \mathrm{f}$ \\
\hline 6 & $65.845 \mathrm{~b}$ & $3677.095 \mathrm{~b}$ & $96.45 \mathrm{~b}$ & $0.972 \mathrm{a}$ & $74 \mathrm{a}$ & $7 \mathrm{c}$ & 19 e \\
\hline 7 & $61.644 \mathrm{~b}$ & $2317.443 b$ & $96.10 \mathrm{~b}$ & $0.961 \mathrm{a}$ & $29 \mathrm{~b}$ & $39 \mathrm{a}$ & $32 \mathrm{~d}$ \\
\hline 8 & $47.116 \mathrm{c}$ & $1491.048 \mathrm{~b}$ & $95.35 \mathrm{~b}$ & $0.965 \mathrm{a}$ & $41 \mathrm{~b}$ & $0 \mathrm{c}$ & $59 \mathrm{~b}$ \\
\hline 9 & $62.149 \mathrm{c}$ & $3355.878 \mathrm{c}$ & $96.90 \mathrm{a}$ & $0.967 \mathrm{~b}$ & $80 \mathrm{a}$ & $0 \mathrm{c}$ & $20 \mathrm{e}$ \\
\hline 10 & $29.851 \mathrm{~d}$ & $870.682 \mathrm{~d}$ & $91.87 \mathrm{c}$ & $0.947 \mathrm{c}$ & $8 \mathrm{c}$ & $16 \mathrm{~b}$ & $76 \mathrm{a}$ \\
\hline Mean & 64.26 & 2901.991 & 96.00 & 0.963 & 51.2 & 16.7 & 32.4 \\
\hline CV (\%) & 5.97 & 9.86 & 0.86 & 0.53 & 19.63 & 43.18 & 28.99 \\
\hline
\end{tabular}

Revista Árvore 2020;44:e4426 
Table 2 - Physiological quality of different $P$. gonoacantha seed lots. Means represented by the same letter do not differ by the Scott-Knott test $(p \leq 0.05)$.

Tabela 2 - Qualidade fisiológica de diferentes lotes de sementes de P. gonoacantha. Médias representadas pela mesma letra não diferem entre si pelo teste de Scott-Knott $(\boldsymbol{p} \leq 0.05)$

\begin{tabular}{|c|c|c|c|c|c|c|}
\hline Lots & $\mathrm{RP}(\%)$ & NS (\%) & $\overline{\text { GSI }}$ & t50 (days) & $\begin{array}{c}\text { SL } \\
\left(\mathrm{mm} . \text { seedling }^{-1}\right)\end{array}$ & $\begin{array}{c}\text { SDM } \\
\left(\mathrm{mg}_{\text {.seedling }}^{-1}\right)\end{array}$ \\
\hline 1 & $95 \mathrm{a}$ & $89 a$ & $4.156 \mathrm{a}$ & $3.674 \mathrm{c}$ & $147.711 \mathrm{~b}$ & $0.015313 \mathrm{~b}$ \\
\hline 2 & $90 \mathrm{a}$ & $80 \mathrm{a}$ & $3.769 \mathrm{a}$ & $3.655 \mathrm{c}$ & $160.276 \mathrm{a}$ & $0.016101 \mathrm{~b}$ \\
\hline 3 & $67 \mathrm{~b}$ & $55 \mathrm{~b}$ & $2.286 \mathrm{~b}$ & $4.432 \mathrm{a}$ & $74.395 \mathrm{c}$ & $0.006949 \mathrm{~d}$ \\
\hline 4 & $71 \mathrm{~b}$ & $58 \mathrm{~b}$ & $2.436 \mathrm{~b}$ & $4.285 \mathrm{a}$ & $75.959 \mathrm{c}$ & $0.008985 \mathrm{c}$ \\
\hline 5 & $91 \mathrm{a}$ & $89 \mathrm{a}$ & $3.957 \mathrm{a}$ & $3.979 \mathrm{~b}$ & $151.336 \mathrm{~b}$ & $0.020077 \mathrm{a}$ \\
\hline 6 & $94 \mathrm{a}$ & $90 \mathrm{a}$ & $4.050 \mathrm{a}$ & $3.823 \mathrm{~b}$ & $136.549 \mathrm{~b}$ & $0.015882 \mathrm{~b}$ \\
\hline 7 & $67 \mathrm{~b}$ & $53 \mathrm{~b}$ & $2.317 \mathrm{~b}$ & $3.953 \mathrm{~b}$ & $68.799 \mathrm{c}$ & $0.006575 \mathrm{~d}$ \\
\hline 8 & $51 \mathrm{c}$ & $38 \mathrm{c}$ & $1.499 \mathrm{c}$ & $4.589 \mathrm{a}$ & $47.132 \mathrm{~d}$ & $0.003551 \mathrm{~d}$ \\
\hline 9 & $95 \mathrm{a}$ & $94 \mathrm{a}$ & $4.408 \mathrm{a}$ & $3.638 \mathrm{c}$ & $164.219 \mathrm{a}$ & $0.017549 \mathrm{~b}$ \\
\hline 10 & $2 \mathrm{~d}$ & $0 \mathrm{~d}$ & $0 \mathrm{~d}$ & $0 \mathrm{~d}$ & $1.998 \mathrm{e}$ & $0.000193 \mathrm{e}$ \\
\hline Mean & 72 & 65 & 2.888 & 3.603 & 102.838 & 0.011117 \\
\hline CV (\%) & 11.72 & 14.79 & 13.81 & 5.32 & 12.16 & 5.97 \\
\hline
\end{tabular}

root protrusion, normal seedlings, and GSI, showed lower values of t50, reinforcing the higher germination speed of these lots. Through the development of seedlings, lots 2 and 9 had higher length and lot 5 had higher dry matter content. As expected by the results previously observed, lot 10 showed shorter seedling length and dry matter when compared to the other analyzed lots (Table 2).

A direct relation between tissue density and the filling of the seeds with their physiological quality was clearly observed. In the three-dimensional representation of density (Figure 2c), colors closer to red represent higher density and colors closer to blue, lower density. Therefore, well-formed seeds (Class 1) showed higher density and, consequently, generated more vigorous seedlings (Figure 2A).

Well-formed and damaged seeds (Class 2) showed a reduction in tissue density and lower seedling vigor. Seeds with damaged cotyledons showed a reduction in seedling development. When the damage was present on the embryonic axis, abnormal seedlings are generated, totally deformed (Figure 2B). In a different way, malformed seeds (Class 3) showed low tissue density, which consequently does not germinate (Figure 2C).

Through the principal component analysis (PCA), the components 1 (PC1) and 2 (PC2) explained $88.8 \%$ of the total variability of the data (Figure $3 \mathrm{~A}$ ).

The PCA results indicated that lots 1, 2, 5, 6 and 9 are located close to the vectors of automated analyses (density, filling, and solidity; gray color), physiological analyses and well-formed seeds (Class 1; blue color). Otherwise, lot 10 is located far from all vectors of automated (gray color), visual (blue color) and physiological (blue color) analyses. Lots 3, 4, 7 and 8 are in an intermediate way to those previously mentioned

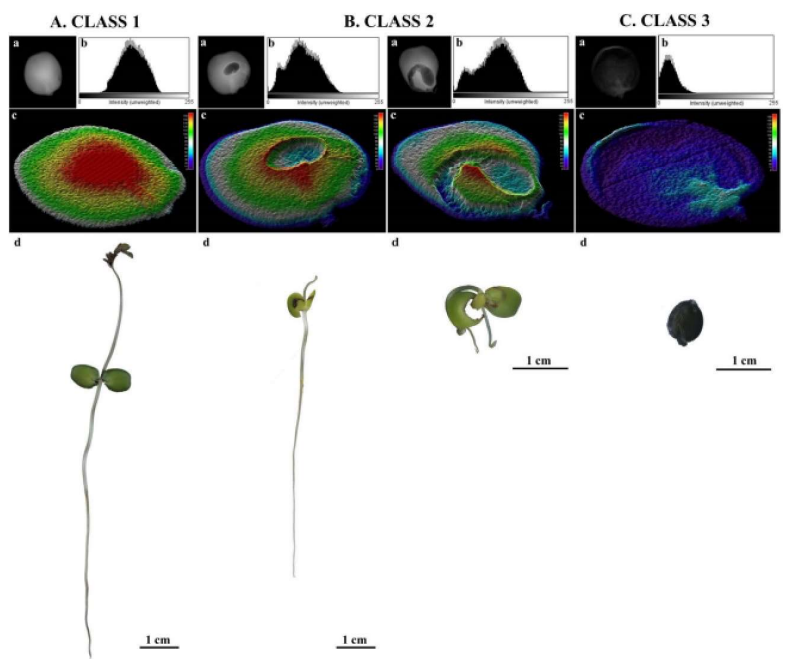

Figure 2 - Relation between tissue density and physiological quality of three classes of $P$. gonoacantha seeds. (a) radiographic images; (b) histogram of relative density; (c) three-dimensional representation of density; (d) seedlings formed.

Figura 2 - Relação da densidade tecidual e da qualidade fisiológica de três classes de sementes de P. gonoacantha. (a) imagens radiográficas; (b) histograma de densidade relativa; (c) representação tridimensional da densidade; (d) plântulas formadas.

\author{
Revista Árvore 2020;44:e4426
}


A Principal Component Analysis

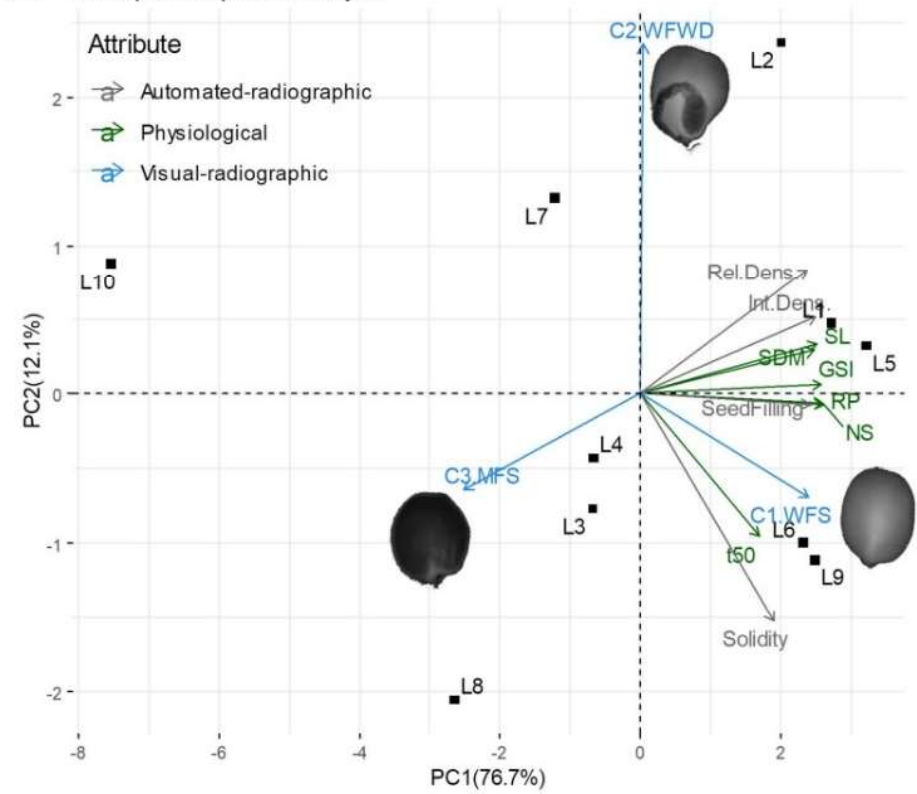

\section{$\mathbf{B}$}

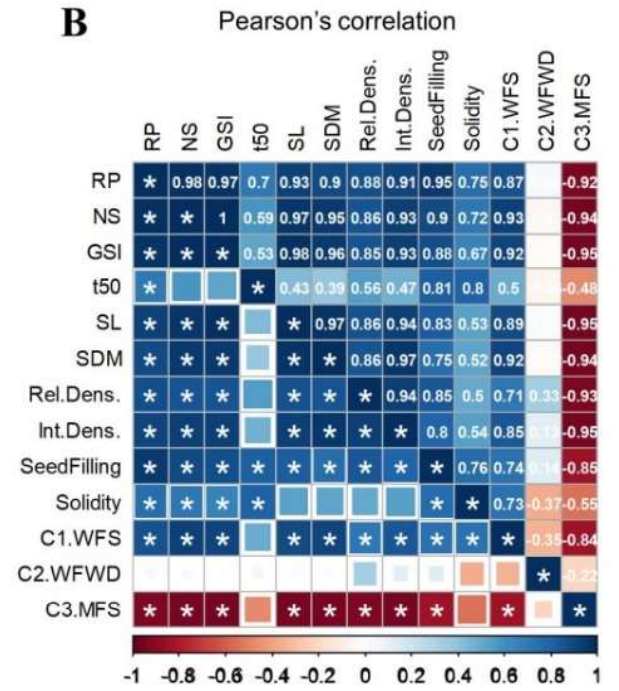

Figure 3 - Biplot obtained by principal component analysis (PCA) (A) and Pearson correlation (r) (B) obtained by the linear combination of the physical and physiological variables of 10 lots of P. gonoacantha. PC1: Principal component 1; PC2: Principal component 2; RP: Root protrusion; NS: Normal seedlings; GSI: Germination speed index; t50: Time to germinate $50 \%$ of the lot; SL: Seedling length; SDM: Seedling dry matter; Rel.Dens .: Relative density; Int. Dens.: Integrated Density; SeedFilling: Filling of the seeds; Solidity: Solidity; C1.WFS: Well-formed seeds (Class 1); C2.WFWD: Well-formed and damaged seeds (Class 2); C3.MFS: Malformed seeds (Class 3). *: Significant correlation at $5 \%$ probability by t-test.

Figura 3 - Biplot obtido pela análise de componentes principais $(P C A)(A)$ e correlação de Pearson $(r)(B)$ obtida pela combinação linear das variáveis fisicas e fisiológicas de 10 lotes de P. gonoacantha. PC1: Componente principal 1; PC2: Componente principal 2; RP: Protrusão radicular; NS: Plântulas normais; GSI: Índice de velocidade de germinação; t50: Tempo para germinação de $50 \%$ do lote; SL: Comprimento de plântulas; SDM: Matéria seca de plântulas; Rel.Dens.: Densidade relativa; Int.Dens.: Densidade Integrada; SeedFilling: Preenchimento das sementes; Solidity: Solidez; C1.WFS: Sementes bem formadas (Classe 1); C2.WFWD: Sementes bem formadas com danos (Classe 2); C3.MFS: Sementes mal formadas (Classe 3). *: Correlação significativa a $5 \%$ de probabilidade pelo teste $t$.

(Figure 3A). By Pearson's correlation analysis, positive and significant correlations between most of the variables analyzed were observed, except for well-formed and damaged seeds (Class 2). The variable malformed seeds (Class 3) showed a negative and significant correlation with most of the other variables analyzed (Figure 3B).

\section{DISCUSSION}

As observed by the automated physical analysis, the lots with higher values of tissue density, filling, and solidity, presented higher germination and vigor. Similarly, the direct relation between tissue density and / or filling with the physiological quality of seeds has already been observed both in forest species such as $L$. leucocephala (Medeiros et al., 2018), M. polymorphum (Faria et al., 2019) and M. oleifera (Noronha et al., 2019), and in other agricultural species such as tomato
(Borges et al., 2019) and Jatropha curcas (Medeiros et al., 2020).

Tissue density and seed filling are directly related to the formation of the embryo and the accumulation of reserves in seeds, which in turn are mobilized to the embryonic axis during the germination process and play a fundamental role in the development of vigorous seedlings (Cheng et al., 2015; Finch-Savage and Bassel, 2016). This information is reinforced when analyzing lots 1, 2, 5, 6 and 9, which, in general, presented higher values in physical (density, filling and solidity) and physiological (germination and seedling development) attributes; and in the number of well-formed seeds (Class 1). In a different way, lot 10 presented a lower tissue density, filling, and solidity; resulting in a high amount of malformed seeds (Class 3), in addition to null germination when compared to the other lots.

Revista Árvore 2020;44:e4426 
$P$. gonoacantha is a species tolerant to some environmental factors and has important characteristics, such as orthodox seeds tolerant to desiccation and storage (Mayrinck et al., 2016), good water use efficiency (Silva and Silva, 2015) and good nitrogen fixation capacity (Bournaud et al., 2018; Oliveira Júnior et al., 2017). However, information on structural damage of seeds of this species is scarce and was demonstrated in this study. In this context, it was found that wellformed and damaged seeds (Class 2) showed damage caused especially by insects, which has recently been reported as a crucial factor in reducing the germination and vigor of L. leucocephala seeds (Medeiros et al., $2019 b$ ). Considering this type of damage, it was also evident that when it was done to the cotyledons, there was a considerable reduction in seedling development (probably due to the reduction of available reserves during germination). In addition, when the damage was located in the embryonic axis, higher were the deleterious effects on the physiological quality seeds, reducing germination capacity and the formation of normal seedlings by up to $100 \%$. These results are similar to those observed in seeds of Terminalia argentea (Gomes et al., 2014) and Platypodium elegans (Gomes et al., 2016), where the germinative percentage of these species was compromised by the presence of malformed tissues and embryos. In a similar way, it was observed that $\mathrm{X}$-ray system is efficient for assessing physical quality of Moquiniastrum polymorphum seeds (Faria et al., 2019). In mature seeds of Pinus pinea, the micro X-ray computed tomography allowed the characterization of the physical damages caused by invasive bugs (Farinha et al., 2018). Therefore, the observed results can serve as a basis for future studies specifically related to insect damage and other types of damage to $P$. gonoacantha seeds.

Principal component analysis (PCA) can be used to interpret variables related to seed quality (Medeiros et al., 2018). In general, this analysis reduces the dimensionality of a group of correlated variables, maintaining the maximum portion of the variation possible. In this context, a new group of uncorrelated variables is created and ordered in an increasing order as to the portion of variation present in the total variation of the original variables. Thus, the results observed in the PCA can be considered efficient to explain the total variability of the data, since the sum of the main components (PC1 and PC2) was higher than $80 \%$
(Jolliffe and Cadima, 2016). Furthermore, the Pearson's correlation analysis reinforced the results observed in the study, trough the significant correlations between physical and physiological variables.

Therefore, these results indicate that both the seed X-ray technique and the automated seedling analysis are efficient to estimate the viability and vigor of the seeds from the descriptors obtained in these analyses. These results are important for future research on $P$. gonoacantha and may further assist the scientific exploration of this species.

\section{CONCLUSIONS}

The seed X-ray technique combined with the automated analysis of the radiographs is efficient in the evaluation of the internal morphology of Piptadenia gonoacantha seeds. The physical integrity of the seed tissues is directly related to the physiological quality and allows the classification of different lots according to their vigor. Visual analysis of digital radiographs is adequate to identify malformation and damage in Piptadenia gonoacantha seeds.

\section{REFERENCES}

Al-Hammad BA, Al-Ammari BS. Seed viability of five wild Saudi Arabian species by germination and X-ray tests. Saudi Journal of Biological Sciences. 2017;24(6):1424-29. doi:10.1016/j.sjbs.2017.04.004

Al-Turki TA, Baskin CC. Determination of seed viability of eight wild Saudi Arabian species by germination and X-ray tests. Saudi Journal of Biological Sciences. 2017;24(4):822-29. doi:10.1016/j.sjbs.2016.06.009

Borges SRS, Silva PP, Araújo FS, Souza FFJ, Nascimento WM. Tomato seed image analysis during the maturation. Journal of Seed Science. 2019;41(1):22-31. doi:10.1590/2317$1545 \mathrm{v} 41 \mathrm{n} 1191888$

Bournaud C, James EK, Faria SM, Lebrun M, Melkonian R, Duponnois R, et al. Interdependency of efficient nodulation and arbuscular mycorrhization in Piptadenia gonoacantha, a Brazilian legume tree. Plant, Cell \& Environment. 2018;41(9):2008-20. doi:10.1111/pce. 13095

Brasil. Lei n ${ }^{\circ}$ 12.651, de 2012. 2012 [citado 
2020 em 24 de março]. Available at: http://www. planalto.gov.br/ccivil_03/_ato2011-2014/2012/lei/ L12651 compilado.htm

Brunes AP, Araújo AS, Dias LW, Villela FA, Aumonde TZ. Seedling length in wheat determined by image processing using mathematical tools. Revista Ciência Agronômica. 2016;47(2):374-79. doi: $10.5935 / 1806-6690.20160044$

Cheng J, Cheng X, Wang L, He Y, An C, Wang Z, et al. Physiological characteristics of seed reserve utilization during the early seedling growth in rice. Brazilian Journal of Botany. 2015;38(4):751-59. doi: 10.1007/s40415-015-0190-6

Faria JCT, Melo LA, Assumpção CRM, Brondani GE, Breier TB, Faria JMR. Physical quality of seeds of Moquiniastrum polymorphum. Brazilian Journal of Biology. 2019;79 (1):63-69. doi:10.1590/15196984.175407

Farinha AO, Branco M, Pereira MFC, AugerRozenberg MA, Maurício A, Yart A, et al. Micro $\mathrm{X}$-ray computed tomography suggests cooperative feeding among adult invasive bugs Leptoglossus occidentalis on mature seeds of stone pine Pinus pinea. Agricultural and Forest Entomology. 2018;20(1):18-27. doi:10.1111/afe.12225

Finch-Savage WE, Bassel GW. Seed vigour and crop establishment: extending performance beyond adaptation. Journal of Experimental Botany. 2016;67(3):567-91. doi: 10.1093/jxb/erv490

Gagliardi B, Marcos-Filho J. Relationship between germination and bell pepper seed structure assessed by the X-ray test. Scientia Agricola. 2011;68(4):41116. doi:10.1590/S0103-90162011000400004

Gomes KBP, Matos JMM, Martins IS, Martins RCC. $\mathrm{X}$-ray test to evaluate the physiological potencial of Platypodium elegans Vog. Seeds (Fabaceae). Scientia Agropecuaria. 2016;7(3):305-11. doi:10.17268/sci. agropecu.2016.03.19

Gomes KBP, Martins RCC, Martins IS, Gomes Junior FG. Avaliação da morfologia interna de sementes de Terminalia argentea (Combretaceae) pelo teste de raios X. Revista Ciência Agronômica. 2014;45(4):752-59. doi:10.1590/S180666902014000400013
Jolliffe IT, Cadima J. Principal component analysis: a review and recent developments. Philosophical transactions. Philos Trans A Math Phys Eng Sci. 2016;374(2065):20150202. doi:10.1098/ rsta.2015.0202

Kassambara A, Mundt F. Factoextra: extract and visualize the results of multivariate data analyses. Version 1. R Package; 2016.

Leão-Araújo EF, Gomes-Junior FG, Silva AR, Peixoto N, Souza ERB. Evaluation of the desiccation of Campomanesia adamantium seed using radiographic analysis and the relation with physiological potential. Agronomy Journal. 2019;111(2):592-600. doi:10.2134/ agronj2018.05.0302

Mayrinck RC, Vaz TAA, Davide AC. Classificação fisiológica de sementes florestais quanto à tolerância à dessecação e ao comportamento no armazenamento. Cerne. 2016;22(1):85-92. doi:10.15 90/01047760201622012064

Medeiros AD, Araújo JO, León MJZ, Silva LJ, Dias DCFS. Parameters based on X-ray images to assess the physical and physiological quality of Leucaena leucocephala seeds. Ciência e Agrotecnologia. 2018;42(6):643-52. doi:10.1590/141370542018426023318

Medeiros AD, Pinheiro DT, Xavier WA, Silva LJ, Dias DCFS. Quality classification of Jatropha curcas seeds using radiographic images and machine learning. Industrial Crops and Products. 2020;146:112162. doi:10.1016/j. indcrop.2020.112162

Medeiros AD, Zavala-León MJ, Araújo JO, Pereira MD, Dias DCFS, Silva LJ. Relationship between internal morphology and physiological quality of Leucaena leucocephala seeds using image analysis. Revista Árvore. 2019;43(2):e430208. doi:10.1590/1806-90882019000200008

Moura MN, Terra V, Garcia FCP. Piptadenia (Leguminosae, Mimosoideae) in the state of Minas Gerais, Brazil. Rodriguésia. 2017;68(1):209-22. doi:10.1590/2175-7860201768126

Noronha BG, Medeiros AD, Pereira MD. Avaliação da qualidade fisiológica de sementes de moringa oleifera lam. Ciencia Florestal. 2018;28(1):393-402.

Revista Árvore 2020;44:e4426 
doi:10.5902/1980509831615

Noronha BG, Pereira MD, Medeiros AD. Incremento de área em sementes de moringa durante a embebição por meio da análise de imagens. Ciência Florestal. 2019;29(1):221-32. doi:10.5902/1980509827289

Oliveira Júnior JQ, Jesus EC, Lisboa FJ, Berbara RLL, Faria SM. Nitrogen-fixing bacteria and arbuscular mycorrhizal fungi in Piptadenia gonoacantha (Mart.) Macbr. Brazilian Journal of Microbiology. 2017;48(1):95-100. doi:10.1016/j. bjm.2016.10.013

R Development Core Team. R: A Language and Environment for Statistical Computing. Vienna, Austria: R Foundation for Statistical Computing; 2018.

Sako Y, McDonald MB, Fujimura K, Evans AF, Bennett MA. A system for automated seed vigour assessment. Seed Science and Technology.
$2001 ; 29(3): 625-36$

Silva LJ, Medeiros AD, Oliveira AMS. SeedCalc, a new automated $\mathrm{R}$ software tool for germination and seedling length data processing. Journal of Seed Science. 2019;41(2): 250-57. doi:10.1590/2317$1545 v 42 \mathrm{n} 2217267$

Silva RBG, Silva MR. Nursery water management on initial development and quality of Piptadenia gonoacantha seedlings. Scientia Florestalis. 2015;43(105):91-100.

Torres CMME, Jacovine LAG, Oliveira Neto SN, Souza AL, Campos RA, Schettini BLS. Análise Fitossociológica e Valor de Importância em Carbono para uma Floresta Estacional Semidecidual. Floresta e Ambiente. 2017;24:e00099714. doi:10.1590/21798087.099714

Yen JC, Chang FJ, Chang S. A new criterion for automatic multilevel thresholding. IEEE Transactions on Image Processing. 1995;4(3):37078. doi:10.1109/83.366472 